\title{
Management Proposal for Consumable Item Control in an Electronic Company Using Concept of Human Reliability and Quality Tools
}

\author{
Polyana Almeida da Silva, Marcelo Albuquerque de Oliveira, Gabriela de Mattos Veroneze, \\ and Camila Maria Costa da Silva
}

\begin{abstract}
This paper will bring a new proposal for the management and control of consumable items in an electronic company at Manaus Industrial Pole, using the concept of human reliability in order to reach a best efficiency of the activities carried out by the coating station operators and also the use of tools like control charts, Ishikawa diagram, 5W2H, and PDCA which when are combined result in the understanding of the problem and also a better management method in the current situation.
\end{abstract}

Key words - Consumable items, Production Planning, Raw Material Management.

\section{INTRODUCTION}

The analysis will come from a company that's part of an electronic manufacturer sector. In this organization, it's developed solutions of energetic efficiency in LED illumination, portable batteries and energy storage solutions. The focus of the industrial plant localized in Manaus city are the portable batteries of ion-lithium, used specially on cell phones and notebooks.

The market of this kind of sector is highly competitive. Therefore, there is a huge necessity to always enhance the development of new products or the ones that already exist, so the buying planning of inputs be the most assertive as possible, trying to avoid huge failures or raw material remains used in the production in large scale.

Within the manufacture of any product, there's always the input demand than previously was programmed to purchase from the data sent by the customer (product's project) The question is that can happen that not even all the items on the list own an exact measurement, for example, the fluid types. From this context, it is going to be developed a theoretical referential that can corroborate with the study to be proposed, taking into account applicable concepts of reliability and the usage of tools of quality in camp.

In the problematic itself, the many positive and negative effects are going to be approached, looking for every improvement opportunity.

\section{LITERATURE REVIEW}

\section{A. Material Planning and Management}

The materials management is applied to all the functioning spheres of manufacture companies and in the most part determines the quality, time, flexibility, and many other essential factors to the parametrization of the main processes. The collect specificity, storage and material allocation in individual spheres of functioning of these companies is a little different and each one of them have their critical points [1].

According to [2], storages are stacks of raw material, inputs, compounds, products in process and finished products that come up in numerous spots through all the logistical channels and from the company's production.

Following the argument, stacks are any quantities of physical goods that are conserved, in a non-productive way, for some time interval; they constitute the stack the finished products that keep the sale or dispatch and also raw-materials and compounds that wait for utilization in the production [3].

According to [4] he says that the classification of the stocks can be considered as auxiliary materials (those that don't incorporate to the final product, also called indirect or nonproductive materials), raw-material (incorporated to the final product, including the packages),products in processes (materials that are in the fabrication process) and finished products (are the materials now under the form of final product, ready to be marketed or delivered).

The author sustains the materials that can be considered surplus (treating of an obsolete material that exists in superior quantity to the users' needs); obsolete material (that doesn't satisfy anymore the company's requirement, because they have been substituted by others); scraped material (which treats the deteriorated material over the time, without any other utilization, that doesn't present another value, or else the inherent of its composition; and the unserviceable material (which as a consequence of the time utilization, deteriorates, becoming useless for its technical recuperation, economically unfeasible).

In organizations, there is a clear need to have clear control over the entire flow of materials: their storage period, the quantity of items kept in each compartment, the frequency of replacement, among others. The areas responsible for

Gabriela de M. Veroneze, Federal University of Amazonas

(e-mail: gveroneze@ufam.edu.br)

Camila M. C. da Silva, Federal University of Amazonas.

(e-mail: camila.silva@ ${ }^{@}$ super.ufam.edu.br) 
managing the inputs need to critically analyze the use of each item in the final product and thus establish a type of planning for future replacement and correct storage, always paying attention to some key points such as expiration dates, supplier lead time and alike.

The PCP area is used to describe planning processes of capacity, materials need, planning shop floor control, orders' production liberation and purchases, within other activities [5]. The PCP that determines what, when, how, where and how many will be produced [6], that is to say, it's the responsible by the materials' stream regulation, from the compounds' acquisition, pieces and inputs until they are transformed in finished products, by the manufacturing process [7]. To assist the planning area, there are tools called MRP MRP (Material Requirement Planning) that uses registered information from BOM (Bill of Materials) of product with its respective use quality. The MRP solution comes from a simple premise: if we can design requirements, with knowledge from the initial stocktaking, we can forecast or calculate when the inputs' refilling point will happen. By knowing this, we must keep the storage low until a little before is needed to produce the next stock of some finished product [8].

The MRP allows the company knows which materials are going to be necessary and in which moment through the production master plan explosion using information's from materials' list, enables to verify the inputs forecast quantities and the quantities that will be delivered from each compound that are necessary to deliver the request, also analyze the stock to verify if already exist available materials ensuring that are purchased only the necessary to time's utilization [9].

\section{B. Human Reliability Concept}

According to [10], human reliability is defined as any method by which reliability on people is estimated. It's the probability of success of human activities which the failures can cause a significant impact in the general reliability of a system man-machine. A second author also affirms that the Human Reliability can be defined as a quality or state of who can be trusted, that is to say, it's the probability of someone succeed in accomplishing his own mission, in a certain period and suitable environmental conditions with the necessary resources available [11].

Some techniques have been developed over the time and can be utilized in the industrial mean. These techniques aim to determine the impact of human mistakes in a system. They are based on systems' engineering and behavioral science methods to understand and evaluate the human contribution to reliability and security of the system [12].

The methodology used can variate according to the system observed. Some of the main techniques are: THERP, SLIMMAUD, the CREAM and the MERMOS.

The method THERP - Technique for Human Error Rate Prediction, is based on the results of a task analysis, which divides a task into many sub tasks. It has been developed to deliver representational modeling of human actions (trees of the event HRA) and the estimative of Human Error Probability (HEP) [13]. The method SLIM-MAUD, according to [14], is based on the supposition that the failure probability associated with the performance of the task comes from a combination of PSFs (Performance Shaping Factors) that includes the individuals', environment, and task characteristics.

The CREAM - The Cognitive Reliability Error Analysis Method, consists basically of a number of groups the describe phenotypes (errors mode, manifestations) and genotypes of wrong actions, where the last refer to a fundamental distinction between a person genotypes, technology and organization related to this nature [14].

MERMOS - Méthode d'Évaluation de la Réalisation des Missions Opérateur la Sûreté, tries to identify the states by observing the teams in operation (answering to accidents in the simulator), considering the previous registers and the specialists' considerations. Because of that, it is aimed at the use of simulator information and data collected by observers denoting the team's action when they are answering a simulated accident [15].

\section{Cause and Effect Diagram}

According to [16], the traditional cause and effect diagram is a management qualitative tool. By using this tool, it is possible to show the relations between cause and effect and lastly do a critical analysis between them [17]. Normally, countless causes can be associated with a problem not classified as machines, methods, materials, measurements, people and environment and after classified by sub causes [18].

The analysis process is clear the relation between causes factors in the process and the effects such as quality, cost, productivity, etc., when enrolled in the control process. The process control tries to discover the cause factors that prevent the light functioning of processes. He searches that the technology can perform preventive control. Quality, cost and productivity are effects or results of this process control [19].

According to [20], there is a technique that enables the diagram mounting to find a relation of cause and effect:

1. Identify the problem.

2. Draw up the main factors involved.

3. Identify possible causes.

4. Lastly, analyze the diagram as a whole.

The causes are generally grouped in principal categories to identify these variation sources. The categories normally include:

- Labor: Any person involved in the process;

- Methods: Once the process has been done and the specific requirements to do it, such as politics, procedures, rules, regulations and laws;

- Machines: Any equipment, computer, tool etc. necessary to do the work;

- Material: Raw materials, pieces, pens, paper, etc., used to produce the final product;

- Measurements: Data generated by the process that are used to evaluate your quality;

- Environment: Conditions, such as localization, time, temperature and culture in which the process operates.

In the Fig. 1, we have the graphic functioning of the tool. 


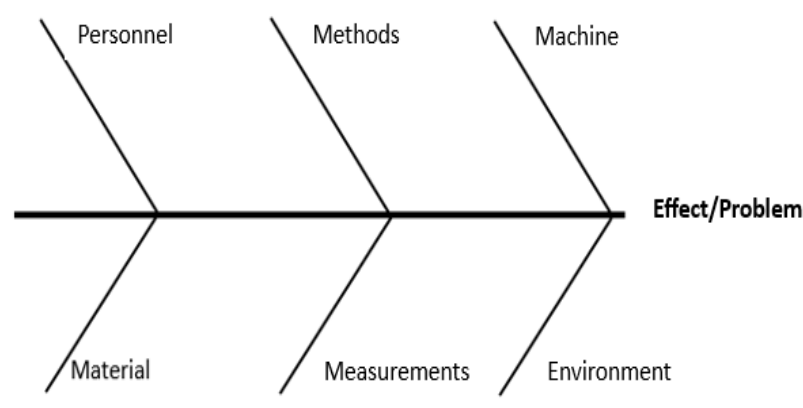

Fig. 1. Cause and Effect Diagram.

\section{Control Charts}

The graphic controls have been initially developed as a tool to monitor and control the fabrication processes [21], who proposed the concept that a graphic or card control shows the quality value characteristic of interest in function of the time or the sample number.

This graphic is constituted by a central line that represents the medium value of control processes of two horizontal lines, the superior limit control (SLC) and the inferior limit control (ILC) [22].

According to Fig. 2, around the line are going to be distributed the spots, in case it doesn't occur any variability in the process, once being the central line the nominal value or target that the quality features should assume.

The superior limits or inferior are going to be noticed when the sample averages or results transpose the control limits, alerting to the need of verification and corrective action of the process [23].

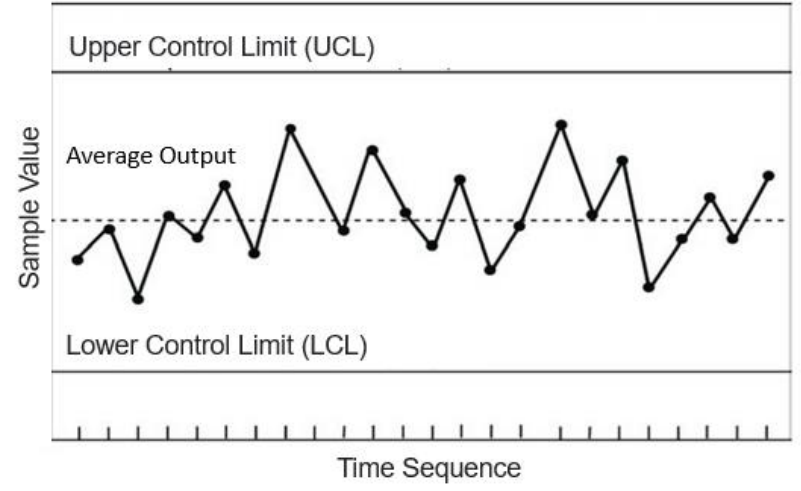

Fig. 2. Cause and Effect Diagram [24].

These control cards are distinguished between two sources of variation: variation of "common cause", which is intrinsic to any process and variation of "special cause", caused by a factor extrinsic to the process. A fundamental characteristic of this classification (variation of common cause vs special cause) is that the necessary actions to solve them are different. Reduce the variation of common cause, we need to change the process in some fundamental way and to variations of special causes, we need to find the extrinsic factor and after act over it [25].

Some preliminary concepts about the statistics have a huge importance for the development and understanding of this tool:

\section{1) Central tendency measures}

Average, median, mode indicate the center around which of the data are going to be normally distributed.

\section{2) Dispersion measures}

The measures of central tendency, though, do not reveal how many data are dispersed around the central value. For that, we need to measure the variability or dispersion of these data. Some measurements are used to measure the variability are the range, the variance and the standard deviation [26].

The range calculation is the fastest measure and most simple to measure the variability. It consists of the difference between the highest and the lowest value of a determined data group. The range is indicated by $\mathrm{R}$ where: range = maximum value - minimum [27].

Population variance $(\sigma 2)$ is defined as the sum of the squares of the deviations divided by the number of data (n) [26]. Sample variance $(s 2)$ is calculated by the sum of the squares of the deviations divided by the number of data minus 1 [27]. For the standard deviation $(\sigma)$, it has calculated the square root of the variance; it is the most important measure of dispersion utilized in quantitative data [26].

\section{E. PDCA}

In many studies, it is observed a certain worry with the scientific method (not only qualitative but also quantitative) to be used. To [28], they constitute a tool of grouping results and obtain a better general comprehension about the phenome that has been analyzed.

The PDCA cycle (Fig. 3), also known as Deming Circle, has been proposed by W.E. Deming, a prominent American specialist in quality management. This cycle includes specially four steps: planning, implementation, inspection and action [29]. The PDCA method is used to manage internal processes in order to ensure the achievement of established objectives, based on information as a factor to guide decisionmaking. This work method is the basic quality management method and the general law of all the aspects of business management [30].

The real objective of PCDA is to enable the methods to be used in the problem solving be planned, executed, verified and patterned. According to [31], the PCDA cycle steps are:

a) Plan: this is the first cycle step, in this phase can be taken as base the information collected in the diagram $6 \mathrm{M}$ and is planned as an action that solves the identified causes.

b) Do: the second cycle step consists in executing the plan that has been elaborated.

c) Check: the third step is the action verification, in this phase is analyses the current situation, it is compared to the previous situation, and is verified if what has been planned was in fact done.

d) Action: the fourth step is the action to be taken against the obtained result. In case the effect has been negative and the problem persists, it is started another cycle, if the effect has been positive and the problem has been solved then it's evaluated the current situation and the changes that proportionate the outreach of the goals so that it can be done a standardization of the utilized system. 


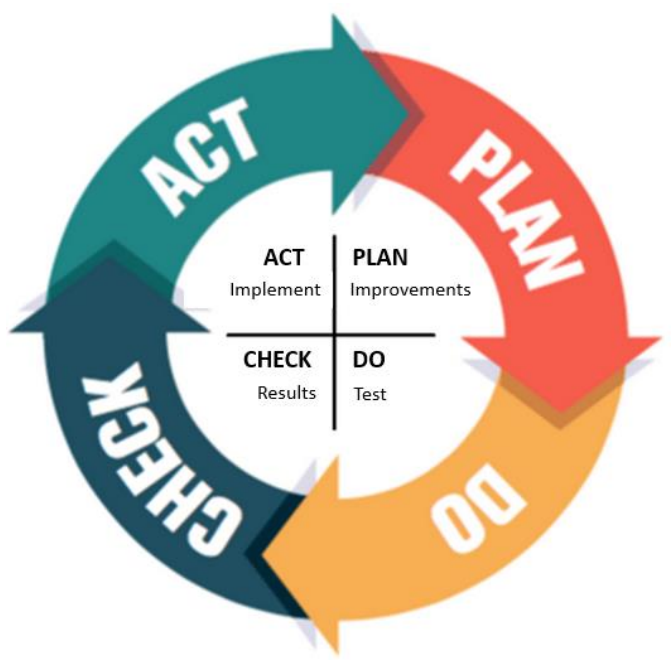

Fig.3. PDCA Cycle [32].

\section{METHODOLOGY}

The methodology applied offers a new proposal of management to consumable items based on information is collected through livingness in camp and official data provided by studies done by the Engineering of company product.

In the first phase of the study, we have a data survey and utilization of statistical tools to validate the quantitative data. In the second phase, we have the application of Ishikawa's diagram to find the causes and propose efficient actions to the problems identified, in the third phase it has been elaborated an action plan with assistance of the tool $5 \mathrm{~W} 2 \mathrm{H}$, and lastly it has been concluded that with the PCDA method to be continuous enhance.

\section{FINDINGS AND DISCUSSIONS}

\section{A. Current Scenario}

The mentioned company uses a MRP (Material Requirement Planning) system to plan and do the rawmaterial requests of its suppliers when it is necessary to supply the process. The most items to fabrication of their finished products are imported sources, with this, we have that Lead Time (time that the material takes to arrive in the factory, from the solicitation of the request) most of the suppliers is of long period time.

The planning area takes into account all the items found in BOM (Bill of Materials) to end its monthly production plan. This BOM composes the product structure within the system and has the materials classified as FP - Finished product; PP - product in process; RM - raw-material and PK - package.

Each item of RM and PK has a consumption value, for example: Product $\mathrm{X}$ takes the quantity of two resistors in the SMD production phase, or Product $Y$ takes a quantity of $5 \mathrm{~cm}$ of scotch tape in the final mounting phase. However not even all the items found in the list have an exact quantity of use, for example the inks, liquid adhesives, and weld in past.

In this article we are going to approach, specifically about the items classified as RM that don't have this exact measurement of how much is spent in the productive process of a final product.
To avoid that the planning have problems with the line stop (shortage) or raw-materials' due date in the stock (leftover), due to this impossibility of knowing in fact how much is spent in production lines, these meetings are been done with the ones involved in the MMT (Material Management), PCP (Planning Control Production), NPI (New Product Introduction) and Supply areas.

To manage this situation, there is a meeting minute (it does not have pattern periodicity established) where shows all the consumable utilized items in the factory and its respective current quantities in stock (indicating shortage or leftover). From the verified values and discussions, the actions are taken by the Production Engineering area that will be responsible for doing consumption studies to each item that represents exorbitant changes diagnosed in these meetings.

To the methodology survey presented in this article, we are going to take as an item of study only the liquid adhesives utilized in the SMD mounting.

\section{B. Consumption Study and Data Survey}

The adhesive in question (Fig. 4) is utilized to set the compounds on the signs during the welding process, that is to say, it is utilized to unite the compounds to the sign in a way that avoids the unwelcome displacement of the compounds during the automated welding process. This kind of adhesive does not modify the compounds' function neither the ones from the electronic circuit.

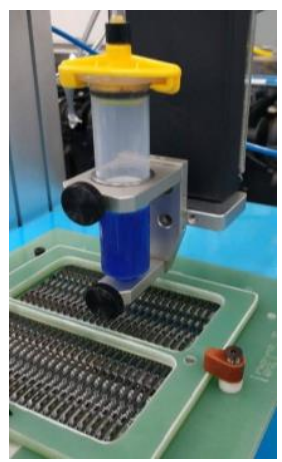

Fig. 4. Adhesive being applied in SMD PCB's.

In the organization are utilized four adhesives from different suppliers (asked according to the initial project). However, they have the same function as mentioned above.

The study has been carried out in order to estimate the use by sigh of "X" kg (unity used in the MRP system) of adhesive with assistance of a precision balance. There are two ways of doing it and both get to approximated results.

The first way is pass through a full tub a certain quantity of signs and collect the liquid value of the adhesive used:

Quantity Utilized adhesive = Quantity full tube - Quantity after use

Right after, divide the number found by the PCB's quantity that have been used:
Consumption $=($ Quantity Utilized adhesive $) /($ Utilized PCB's)

The second way is done by collecting a certain quantity of blanks containing the signs before the adhesive application 
and collection of its weight after the application of the adhesive (this way allows us to have a sample quantity equivalent - normally 10 blanks containing 10 or 16) as shown in Table I.

TABLE I: CONSUMPTION BY BLANK (16 PCB's) - MODEL "X"

\begin{tabular}{ccc}
\hline \hline BLANK & Before & After \\
\hline Sample 1 & 14,232 & 14,396 \\
Sample 2 & 14,563 & 14,733 \\
Sample 3 & 14,263 & 14,433 \\
Sample 4 & 14,296 & 14,463 \\
Sample 5 & 14,308 & 14,445 \\
Sample 6 & 14,472 & 14,604 \\
Sample 7 & 14,439 & 14,573 \\
Sample 8 & 14,560 & 14,695 \\
Sample 9 & 14,420 & 14,554 \\
Sample 10 & 14,429 & 14,561 \\
Final weight & 143,982 & 145,457 \\
\hline \hline
\end{tabular}

In the Table I, we have the value collected in camp. After this, we determine the consumption by blank:

Total=Peso Final weight (After) - Final weight (Before) (3)

Once we have the total, we can obtain the consumption by blank:

\section{Consumption by Blank=Total/10}

Lastly, we can obtain the consumption value by PCB (in this case, each blank has 16 PCB's, study with total sample of 160 PCB's)

Real consumption by $\mathrm{PCB}=($ Consumption by blank $) / 16(5)$

The consumption values found by this piece are kept in only one file with the aim of having an historic to posterior revision. From these data, a statistical study will be done with the assistance of the Control Cards so that can be defined the real size of the variation of the use of the item being studied.

The data collected to the development of this work refers to the consumption of 2019 to one of the adhesives used in a model "X" of SMD sign, remembering that all the studies in the current scenario don't use to follow a pattern peridiciocity: they are done only when there are divergences in the production plan and stock of these materials (according to the meeting minute).

We have a total of 5 consumption samples collected from July to November of 2019. In each month, it has been withdrawn the measurement to constitute the database (5 samples), that are presented with the average and amplitude calculation of each one of them (Table II).

From this, it is calculated:
General average $(\mathrm{P})$ : average of the averages (X_Bar) of each one of the samples:

$$
\mathrm{P}=0,019968
$$

Amplitude average (R-bar): average of the values found to amplitude (R) of each one of the samples.

$$
\text { R_bar }=0,022596
$$

Standard deviation $(\sigma)$ : average of the amplitudes divided by the statistical constant $\mathrm{d} 2$ to each $\mathrm{n}$ value of sample (which $\mathrm{n}=5, \mathrm{~d} 2=2,326)$

$$
\begin{aligned}
& \sigma=R \_ \text {bar } / d 2 \\
& \sigma=0,009715
\end{aligned}
$$

From this, we can calculate the superior, inferior and medium limits to X_bar e R_bar:

$$
\begin{aligned}
& \text { LSC X_bar }=\mathrm{P}+\left(3^{*} \sigma\right) / \sqrt{ } \mathrm{n} \\
& \text { LM X_bar=P } \\
& \text { LIC X_bar }=\mathrm{P}-\left(3^{*} \sigma\right) / \sqrt{ } \mathrm{n} \\
& \mathrm{LSC} \mathrm{R}=\mathrm{R} \_ \text {bar }+3 * \mathrm{~d} 3 * \sigma \\
& \text { LM R=R_bar } \\
& \text { LIC R=R bar-3*d3* } \sigma
\end{aligned}
$$

Which the statistical constant $\mathrm{d} 3=0,8641$, refers to the number of samples $n=5$. In the Table III below, we have all the calculated values.

TABLE III: SUPERIORS, INFERIORS AND MEDIUM LIMITS

\begin{tabular}{ccccccc}
\hline \hline \multirow{2}{*}{ Model X } & $\begin{array}{c}\text { LSC } \\
\text { Xbar }\end{array}$ & $\begin{array}{c}\text { LM } \\
\text { Xbar }\end{array}$ & $\begin{array}{c}\text { LIC } \\
\text { Xbar }\end{array}$ & LSC R & LM R & LIC R \\
\hline Sample 1 & 0,0330 & 0,0199 & 0,0069 & 0,0477 & 0,0226 & 0 \\
Sample 2 & 0,0330 & 0,0199 & 0,0069 & 0,0477 & 0,0226 & 0 \\
Sample 3 & 0,0330 & 0,0199 & 0,0069 & 0,0477 & 0,0226 & 0 \\
Sample 4 & 0,0330 & 0,0199 & 0,0069 & 0,0477 & 0,0226 & 0 \\
Sample 5 & 0,0330 & 0,0199 & 0,0069 & 0,0477 & 0,0226 & 0 \\
\hline \hline
\end{tabular}

The results are shown in the following graphics (see Fig. 5 and Fig. 6).

Analyzing the Fig. 5, where we can visualize the variation from the calculated measures, we can clearly conclude that the consumption of this adhesive over the studied period has presented levels above the superior limit and doesn't have a constancy, such as in the Fig. 6 also, where we can verify variations from its amplitude. The consumption levels are totally out of statistical control.

TABLE II: SAMPLES (JULY - NOVEMBER)

\begin{tabular}{ccccccc}
\hline \hline Samples $(n)$ & Measure July & $\begin{array}{c}\text { Measure } \\
\text { August }\end{array}$ & $\begin{array}{c}\text { Measure } \\
\text { September }\end{array}$ & $\begin{array}{c}\text { Measure } \\
\text { October }\end{array}$ & $\begin{array}{c}\text { Measure } \\
\text { November }\end{array}$ & $\begin{array}{c}\text { Average } \\
(X-b a r)\end{array}$ \\
\hline Samples 1 & 0,0136276 & 0,0080093 & 0,0082992 & 0,0010081 & 0,00112154 & 0,006413148 \\
Sample 2 & 0,0659123 & 0,0588816 & 0,0485845 & 0,0047753 & 0,07854664 & 0,051340068 \\
Sample 3 & 0,0052025 & 0,0059632 & 0,0084716 & 0,0064846 & 0,00948525 & 0,00712143 \\
Sample 4 & 0,0209538 & 0,0215706 & 0,0185647 & 0,0156548 & 0,01965546 & 0,019279872 \\
Sample 5 & 0,0090886 & 0,0103325 & 0,0099851 & 0,0235464 & 0,02548167 & 0,015686854 \\
\hline \hline
\end{tabular}




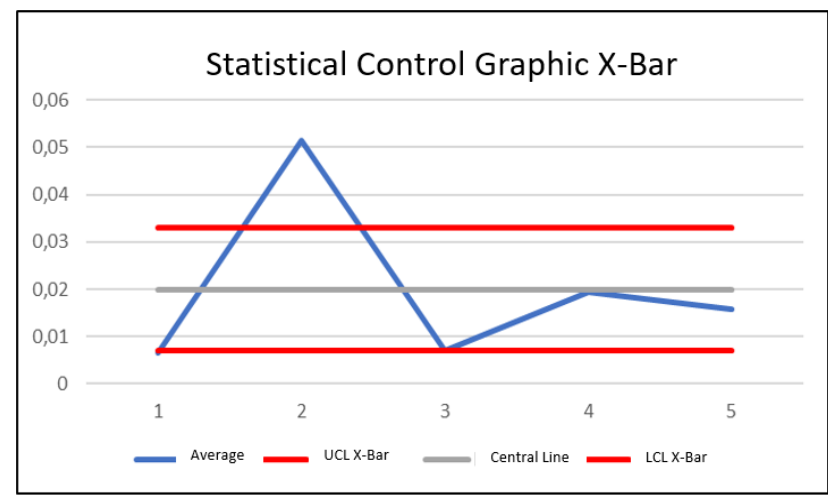

Fig. 5. Statistical Control Graphic X-Bar.

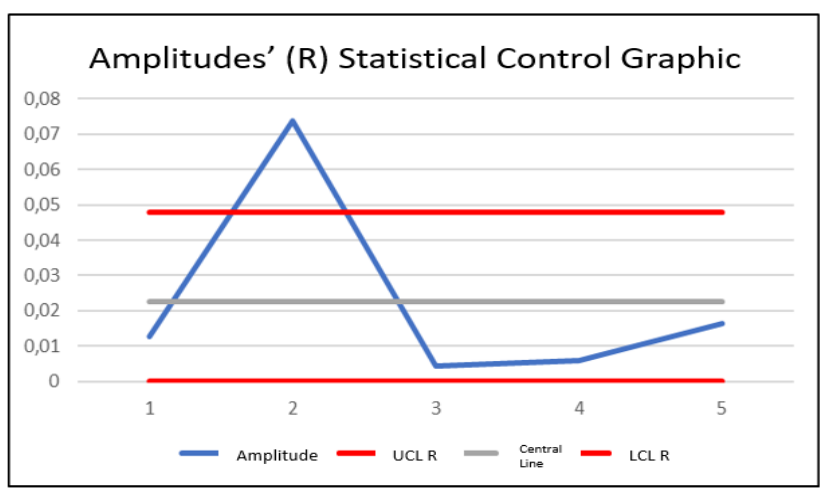

Fig.6. Amplitudes' (R) Statistical Control Graphic.

Noticing the divergence value, from its study, a discussion is opened between the members involved to know if the value of use in the MRP system must be adjusted to adjusting to the planning aiming to be the most assertive as possible.

With all the surveyed data, we can propose and enhance the study done in camp, the use of some quality tools that help with the management efficiency and control of this kind of input.

\section{Results Analysis}

As a proposal to create a management routine more efficient in these items control over the time, the PCDA model can be utilized. The aim is to understand in fact how the mentioned problem comes up, and how it must be solved, with the focus bigger on the cause than the consequences. From the identification of the opportunity of enhancement, are put into practice actions to promote the necessary change and achieve the awaited objectives, that in this case is try to avoid the failures in the maximum in the production planning.

In the phases previously mentioned in this article, applied to the studied case, we have:

- Planning: To develop a strategic map, it is necessary to find the root cause of the problem discussed. With this objective, it is going to utilize the tool known as Ishikawa's diagram.

To the application of the Cause and effect diagram (Ishikawa), there are going to be selected the main reasons that can cause variation in the consumption of the SMD adhesive within the process. This way, it's avoided to get to wrong conclusions, because the wrong survey of the causes can make the decision making inefficient or even harmful.

As explained before, this diagram has the 6M's (Method,
Machine, Man, Mother Nature, Measurement and Material):

1) Method: Wrong machine program of the adhesives' application spots in the SMD signs can take to a higher or lower consumption than the normal.

2) Material: Adhesives in conditions of next due dates or already overdue, can become hardened and change the normal consumption level; the supplier change can modify the chemical conditions of the adhesive, with this change also its consumption levels (personal of each supplier).

3) Machine: The right calibration in the pressure levels can change the item consumption; the maintenance on time of the adhesive application machines can also affect the process.

4) Man: The operator does not have adequate training to operate the machine correctly.

5) Mother Nature: It might have absence of instruction and manuals next to the workplace; the environment temperature can bring alterations (normally very low but must be considered) in the process.

6) Measurements: Incorrect reading of the project to establish the application spots (measures) necessary to be programmed; chance of project and lack of communication between the involved ones.

Still in the first phase, in parallel to Ishikawa's application and identification of actions to be taken, it must be used the called 5W2H (Table V), to plot the general planning aiming to help to make the execution become much clearer and more effective.

1. What (what is going to be done?) Establish a weekly periodicity to do the camp study of the consumable items. From Ishikawa 's diagram, always search working in camp in the possible spotted cause by the tool. If the problem already has a high criticality level, search for damming your house (according to the indicated actions) right away in the process.

2. Why (why is it going to be done?) To avoid or even do not reach critical levels and out of the statistical curve control maintaining a higher database to posterior historic.

3. Where (where is it going to be done?) On the own factory floor.

4. When (is it going to be done?) Weekly.

5. Who (by whom is it going to be done?) Engineering teams with planning and materials assistance.

6. How (how is it going to be done?) Through the compliance of the actions in camp and discussions during meetings about the subject.

7. How much (how much is it going to cost?) Depending on the cause found by the $6 \mathrm{M}$, zero costs. Except for supplier's failure and outsourced maintenance that are going to demand additional costs.

Giving continuation about the PCDA method, we have:

- Execution: Execute the plan according to what has been agreed in the first phase.

- Verification: Verify if the actions taken were, in fact, efficient to the problem in question.

- Action: Analyze the scenario after the realization of three previous steps, verifying its positive and negative spots, with the aim to implement enhancements to the next cycle. 


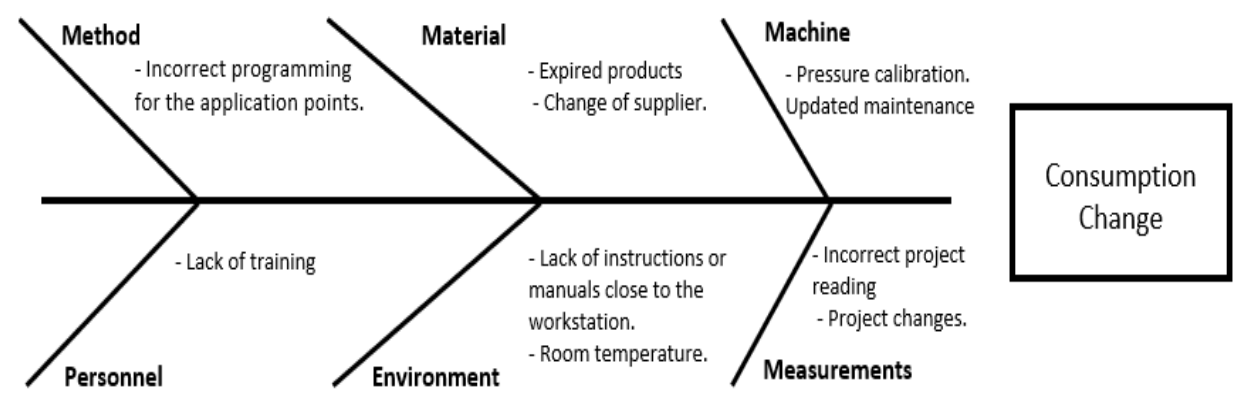

Fig.7. Ishikawa's Diagram of the Process.

TABLE IV: ACTION PLAN 5W2H

\begin{tabular}{|c|c|c|c|}
\hline 6M's & Cause & Action & Responsible team \\
\hline Method & $\begin{array}{l}\text { Incorrect programming } \\
\text { of application points }\end{array}$ & Correct the programming, using the Gerber files & $\begin{array}{l}\text { Product Engineering/SMT } \\
\text { Engineering }\end{array}$ \\
\hline \multirow[b]{2}{*}{ Material } & $\begin{array}{l}\text { Adhesives expired / to } \\
\text { expire }\end{array}$ & $\begin{array}{l}\text { Initiate qualitative negotiations to verify whether the consistency of the } \\
\text { products can still be used in the process or not }\end{array}$ & Quality Engineering \\
\hline & Change of supplier & $\begin{array}{l}\text { Check with the supplier the chemical specifications contained in the } \\
\text { product before using it in Mass Production }\end{array}$ & $\begin{array}{l}\text { Product } \\
\text { Engineering/Quality } \\
\text { Engineering }\end{array}$ \\
\hline \multirow{2}{*}{ Machine } & $\begin{array}{l}\text { Correct pressure } \\
\text { calibration }\end{array}$ & $\begin{array}{l}\text { Check if the pressure calibration of the machine used is correct or if it } \\
\text { needs some kind of adjustment }\end{array}$ & SMT Engineering \\
\hline & Maintenance up to date & $\begin{array}{l}\text { Check if the machine maintenance is up to date, applying corrective } \\
\text { and preventive measures in accordance with the established plan }\end{array}$ & Maintenance Engineering \\
\hline Manpower & Lack of training & $\begin{array}{l}\text { Conduct efficient training of operators responsible for the adhesive } \\
\text { application post work station }\end{array}$ & $\begin{array}{l}\text { SMT } \\
\text { Engineering/Occupational } \\
\text { Safety Engineering }\end{array}$ \\
\hline \multirow[t]{2}{*}{ Mother Nature } & $\begin{array}{l}\text { Lack of instructions and } \\
\text { manuals }\end{array}$ & $\begin{array}{l}\text { Check if there are instructions and physical manuals at the workstations } \\
\text { serving as an aid to the operator. Otherwise, request printing. }\end{array}$ & $\begin{array}{l}\text { SMT } \\
\text { Engineering/Occupational } \\
\text { Safety Engineering }\end{array}$ \\
\hline & Room temperature & Frequently check how the room temperature is regulated & SMT Engineering \\
\hline \multirow{2}{*}{ Measurements } & Incorrect design reading & $\begin{array}{l}\text { Review the initial project file so that there are no errors when passing } \\
\text { on the necessary information to the SMD area }\end{array}$ & Product Engineering \\
\hline & Project changes & $\begin{array}{l}\text { Communicate all involved team if there is any kind of change in the } \\
\text { initial project, review all Gerber files }\end{array}$ & $\begin{array}{l}\text { Product Engineering/SMT } \\
\text { Engineering }\end{array}$ \\
\hline
\end{tabular}

TABLE V: ACTION PLAN 5W2H

\begin{tabular}{|c|c|c|c|c|}
\hline Class & Phase & & Activity & \\
\hline \multirow{5}{*}{$5 \mathrm{~W}$} & What & $\begin{array}{l}\text { Based on the Ishikawa diagram, always try } \\
\text { to act in the field on the possible cause } \\
\text { pointed out by the tool }\end{array}$ & $\begin{array}{l}\text { If you already have a high criticality level, } \\
\text { try to stop your cause (according to } \\
\text { indicated actions) immediately in process }\end{array}$ & $\begin{array}{l}\text { Make the field study } \\
\text { something periodic } \\
\text { (weekly) }\end{array}$ \\
\hline & Why & $\begin{array}{l}\text { To avoid or even not reach critical levels } \\
\text { and outside the statistical control curve }\end{array}$ & $\begin{array}{l}\text { Address the root cause of the identified } \\
\text { problem }\end{array}$ & $\begin{array}{l}\text { Keep a larger database for } \\
\text { later history }\end{array}$ \\
\hline & Where & Plant floor & Plant floor & Plant floor \\
\hline & Who & Engineering teams and auxiliary areas & Engineering teams and auxiliary areas & $\begin{array}{l}\text { Engineering teams and } \\
\text { auxiliary areas }\end{array}$ \\
\hline & When & After problem identification & $\begin{array}{l}\text { After problem identification and criticality } \\
\text { verification }\end{array}$ & Weekly \\
\hline \multirow[b]{2}{*}{$2 \mathrm{H}$} & How & $\begin{array}{l}\text { Field action, as indicated above on the } 6 \mathrm{M} \\
\text { model }\end{array}$ & $\begin{array}{l}\text { Field action, as indicated above on the } 6 \mathrm{M} \\
\text { model }\end{array}$ & $\begin{array}{l}\text { Field study and meeting } \\
\text { discussion }\end{array}$ \\
\hline & How Much & $\begin{array}{l}\text { Depending on the cause found by the } 6 \mathrm{M} \text {, } \\
\text { cost zero. Except for outsourced supply } \\
\text { and maintenance failures that will demand } \\
\text { additional costs }\end{array}$ & $\begin{array}{l}\text { Depending on the cause found by the } 6 \mathrm{M} \text {, } \\
\text { cost zero. Except for outsourced supply } \\
\text { and maintenance failures that will demand } \\
\text { additional costs }\end{array}$ & Zero cost \\
\hline
\end{tabular}

\section{CONCLUSION}

Supplying the needs of a productive process in an efficient and assertive way is one of the hindrances that most of the factories face in their daily routine. It is necessary to search for alternatives that focus on processes well defined so that they can achieve in fact the continuous enhancement.

From the developed proposal in this article, it is clear that the good use of the quality tools available, assist having a management of raw-materials non-measurable (consumable items) within the production control and planning.

Following the PCDA method, we are going to have a wider vision and a higher control over the actions to be taken related to each cause. Your application consists of creating a maintenance routine more efficient for these kinds of input.

Besides that, it has been presented in Ishikawa's Diagram of Cause and Effect that has focused on identifying the consumption root variation, once can exist more than one reason to take to an unbalanced statistical control. Once it is known the root cause, we can eliminate or avoid the same from happening in the future.

Once identified the man as the main cause of Ishikawa's Diagram, we notice also that the importance of the organization dominates the techniques that aim to the human 
reliability, this is going to keep its process more efficient in the products' fabrication. In parallel, it has also used the tool $5 \mathrm{~W} 2 \mathrm{H}$ to mount a solid and defined action plan to be put into practice. The initial objective is to present an enhancement proposal to the management of the consumable items has been achieved. According to what has been explained, it has been shown in this article how to identify the problems, present actions and at last establish an enhancement routine to the company in question.

\section{ACKNOWLEDGMENT}

The authors thank the Production Engineering Department (DEP) of the Federal University of Amazonas (UFAM) for their support and structure.

Special acknowledgement to the institutions and people involved to the final consolidation of this work that has been authorized through the agreement 001/2020 from the Cooperação Técnico-Científica celebrated between Fundação Universidade do Amazonas (FUA), Fundação de Apoio ao Ensino, Pesquisa, Extensão e Interiorização do IFAM (FAEPI) and the company Samsung Eletrônica da Amazônia LTDA (SEDA-M), within the project's scope of capacitation and research, which has been done by the academic unity FTUFAM.

\section{REFERENCES}

[1] Kulińska Ewa. Importance of Costs of Risks in Material Management. E. Kulinska, Importance of Costs of Risks in Material Management. Foundations of Management, [S. 1.], v. 6, n. 1, p. 7-20, 2015 Available at: https://doi.org/10.1515/fman-2015-0001.

[2] R. H. Ballou, Business Logistics/Supply Chain Management and Logware CD Package. 5a ed., Prentice Hall, 816 p., 2003.

[3] T. Borges; M. Campos, and E. Borges, Implantação de um sistema para o controle de estoques em uma gráfica/editora de uma universidade. Revista Eletrônica Produção \& Engenharia, [S. 1.], v. 3, n. 1, p. 236247, 2010.

[4] J. J. Viana, Administração de materiais: um enfoque prático. [S. 1.]: Atlas, 2000. E-book. Available at: https://books.google.com.br/books?id=MnSqPgAACAAJ.

[5] J. K. Porter, P. Jarvis, D. Little, J. Laakkmann, C. Hannen and M. Schotten, "Production planning and control system developments in Germany", International Journal of Operations \& Production Management, Vol. 16 No. 1, pp. 27 39. https://doi.org/10.1108/01443579610106346, 1996.

[6] L. Krajewski, L. Ritzman, and M. Malhotra, Administração de Produção e Operações. São Paulo: Pearson Prentice Hall, 2008. Ebook.

[7] U. Wemmberlöv, Planejamento e controle da produção para sistemas da manufatura celular. São Paulo: IMAM, 1996. E-book.

[8] S. N. Chapman, The Fundamentals of Production Planning and Control. New Jersey: Pearson Education, Inc., 2006. E-book.

[9] N. Slack, S. Chambers, and R. Johnston, Operation Management McGraw-Hill/Irwin; 10th edition, 906 p., 2008.

[10] Y. Fujita, Human reliability analysis: a human point of view. Mitsubishi Atomic Power Industries, Inc., 4-1, Shibakouen 2-Chome, Minato-ku. Japan, 1992.

[11] C. A. Pallerosi, B. P. M. Mazzolini, and L. R. Mazzolini, Confiabilidade Humana: conceitos, análises, avaliação e desafios. São Paulo: All Print Editora, 2011.

[12] F. Chandler, Y. Chang, A. Mosleh, J. Marble, R. Boring, and D. Gertman, Human reliability analysis methods: selection guidance for NASA. Washington, 2006.

[13] D. I. Gertman, H. Blackman; J. Marble, J. Byers, and C. Smith, The SPAR-H Human Reliability Analysis Method. U.S. Nuclear Regulatory Commission (NUREG) - Idaho National Laboratory, Washington, 2005.

[14] E. Hollnagel, Cognitive Reliability and Error Analysis Method. 1. Ed. New York: Elsevier, 1998.
[15] S. Xavier, J. Paula, and A. Ferreira, Confiabilidade humana: um comparativo de métodos. Universidade Federal de Pelotas, 2018.

[16] K. Ishikawa, Asian Productivity. Guide to Quality Control. [S. 1.]: Asian Productivity Organization, 1986. (Industrial engineering and

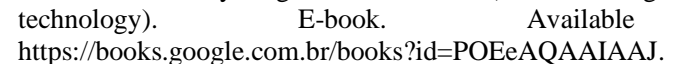

[17] A. Qwiazda, Technical project management using quality methods. Journal of Achievements in Materials and Manufacturing Engineering, [S. 1.], v. 31, n. 2, p. 739-746, 2008.

[18] M. Rodgers, and R. Oppenheim, Ishikawa Diagrams and Bayesian Belief Networks for Continuous Improvement Applications. TQM Journal, [S. 1.], v. 31, p. 294-318, 2019. Available at: https://doi.org/10.1108/TQM-11-2018-0184.

[19] K. Ishikawa, What is Total Quality Control: the Japanese Way. Prentice Hall Direct, 215 p., 1991

[20] L. Liliana, A new model of Ishikawa diagram for quality assessment IOP Conference Series: Materials Science and Engineering, [S. 1.], v. 161 , n. 1, 2016. Available at: https://doi.org/10.1088/1757899X/161/1/012099.

[21] W. A. Shewhart, Economic Control of Quality of Manufactured Product. [S. 1.]: American Society for Quality Control, 1931. (Bell Telephone Laboratories series).E-book. Available at https://books.google.com.br/books?id=XBeoAgAAQBAJ.

[22] M. Riaz, and F. Muhammad, An application of control charts in manufacturing industry. Journal of Statistical and Econometric Methods, [S. 1.], v. 1, n. 1, p. 77-92, 2012. Available at: http://hdl.handle.net/10419/58015.

[23] D. C. Montgomery, Introduction to Quality Statistic Control, Wiley; 8th edition, 768 p., 2020.

[24] R. Martins, Conceitos básicos de controle estatístico da qualidade, 2010 ,

https://www.researchgate.net/publication/323704207_Conceitos_basi cos_de_controle_estatistico_da_qualidade.

[25] R. Tennant et al., Monitoring patients using control charts: a systematic review. International Journal for Quality in Health Care, [S. 1.], v. 19 n. $4, \quad$ p. $187-194,2007 . \quad$ Available at: https://doi.org/10.1093/intqhe/mzm015.

[26] M. C. Rodrigues, Aplicação de Cartas de Controle nas Análises de Rotina do Laboratório de Qualidade do Leite da Embrapa Gado de Leite. 2015. - UFJF, [s. 1.], 2015. Availabre at: https://repositorio.ufjf.br/jspui/handle/ufjf/1447.

[27] S. Vieira, Estatística para Qualidade 3a ed. Rio de Janeiro: Elsevier, 2012. E-book

[28] R. C. F. Pereira, Explorando conceitos e perspectivas da meta-análise em marketing. In: 2004, Rio de Janeiro. Encontro da Associação Nacional de Pós-Graduação e Pesquisa em Administração. Rio de Janeiro: ANPAD, 2004

[29] Y. Chen, and L. Haoqi, Research on Engineering Quality Management Based on PDCA Cycle. IOP Conference Series: Materials Science and Engineering, [S. 1.], v. 490, n. 6, 2019. Available at: https://doi.org/10.1088/1757-899X/490/6/062033.

[30] J. Y. Mei, M. B. Zhang, and B. Zhou, Research on the hydrological emergency monitoring system of high-risk Barrier Lake based on PDCA theory. IOP Conference Series: Earth and Environmental Science, [S. 1.], v. 344, n. 1, 2019. Available at https://doi.org/10.1088/1755-1315/344/1/012103.

[31] M. C. C. Werkema, Ferramentas estadísticas básicas para o gerenciamento de processos. [S. 1.]: Universidade Federal de Minas Gerais. Escola de Engenharia. Fundacao Christiano Ottoni, 1995 (Série ferramentas da qualidade).E-book. Available at https://books.google.com.br/books?id=ZAjrAAAACAAJ.

[32] C. Júnior, Ciclo PDCA, uma ferramenta imprescindível ao gerente de projetos, 2019. http://www.doxplan.com/Noticias/Post/Ciclo-PDCA,uma-ferramenta-imprescindivel-ao-gerente-de-projetos.

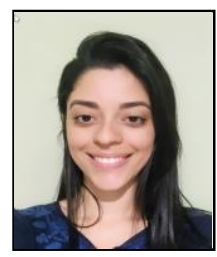

Polyana Silva is a student is a student of Production Engineering at the Federal University of Amazonas, and researcher under SUPER project. 


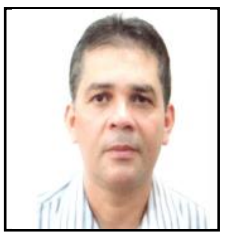

Marcelo Oliveira is an Adjunct Professor of

Department of Production Engineering and member of Master Program in Production Engineering, Federal University of Amazonas. He has published several Research Papers related to Engineering area.

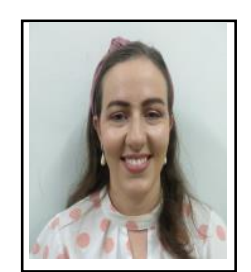

Gabriela Veroneze is an Adjunct Professor, Department of Production Engineering and member of Master Program in Production Engineering, Federal University of Amazonas. She has published several Research Papers related to Engineering area.

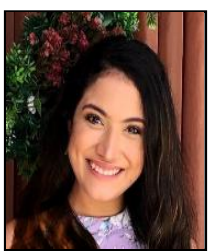

Camila Silva is a student is a student of Production Engineering at the Federal University of Amazonas, and researcher under SUPER project. 